\title{
ACCOUNTABILITY COMO FERRAMENTA DE DESENVOLVIMENTO, CIDADANIA E CONTROLE SOCIAL
}

\author{
Telma Regina STROPARO ${ }^{*}$; Marina STROPARO²
}

\begin{abstract}
${ }^{1}$ Contadora; Mestre em Desenvolvimento Regional; Doutoranda em Geografia/Universidade Estadual de Ponta Grossa (UEPG); Professora Efetiva/Universidade Estadual do Centro-Oeste (UNICENTRO), Irati, Paraná, Brasil. ${ }^{2}$ Graduada em Ciências Contábeis/UNICENTRO; Consultora do curso de Empreendedorismo, vinculado ao Bom Negócio Paraná; Tutora/Centro de Ensino Superior de Maringá (UniCesumar), Maringá, Paraná, Brasil.

*Autora para correspondência. E-mail: telma@unicentro.br
\end{abstract}

A obrigatoriedade de transparência nos atos da administração pública relaciona-se ao conceito de accountability, palavra de origem inglesa e sem tradução para o português, mas que hodiernamente tem sido associada à obrigação dos administradores públicos, enquanto gestores da coisa pública, em prestarem contas de suas ações e de por elas se responsabilizarem, perante a sociedade. A relação entre accountability, transparência e desenvolvimento territorial é importante, pois permeia a responsabilidade dos agentes públicos na correta aplicação de recursos públicos em ações que se traduzam em efetividade e responsabilidade social. Por outro lado, tem-se uma sociedade mais atuante e crítica que observa, analisa e exige não só a aplicação efetiva dos recursos públicos, como também a transparência dos atos da administração pública. Desenvolvimento territorial passa, indubitavelmente, pelos dois enfoques: aplicação dos recursos públicos e transparência dos atos e consequente diminuição da pobreza, melhoria na qualidade da vida da população abrangida pelos programas/ações, acesso aos programas sociais, às políticas de trabalho e renda, dentre outros. Nesse sentido, a presente pesquisa classifica-se, metodologicamente, em exploratória e descritiva e, quanto aos objetivos, em bibliográfica e documental. Propõe o levantamento e análise do nível de transparência dos atos públicos, relacionados à área de promoção social, trabalho e renda, disponíveis nos Portais de Transparência dos municípios que compõe a Associação dos Municípios do Centro Sul do Paraná (AMCESPAR). A amostra é composta pelos dez municípios que compõe a AMCESPAR. Foram coletados dados relativos aos anos de 2014 a 2019. Os dados coletados apontam para o fato de que houve evolução significativa na transparência e divulgação dos atos públicos. No entanto, foram detectadas falhas e/ou falta de transparência nos portais analisados indicando que há um longo caminho a ser desenvolvido quando o assunto é accountability. As informações não são apresentadas de forma detalhada, a linguagem é técnica, a forma disponibilização é confusa e diferente em cada portal.

Palavras-chave: Desenvolvimento; Accountability; Transparência; Controle Social. 